\title{
Where Will the Future Be Heading Towards? A Book Review for "The Belt and Road Strategy in International Business and Administration"
}

\author{
Zi-Miao Gao ${ }^{1}$, Xiao-Guang Yue ${ }^{2}$ and Xiao-Jing $\mathrm{Li}^{3, *}$ \\ 1 Discipline of Finance, The University of Sydney Business School, Sydney 2006, Australia \\ 2 Rattanakosin International College of Creative Entrepreneurship, Rajamangala University of Technology \\ Rattanakosin, Phutthamonthon 73170, Thailand \\ 3 Business School, Qingdao University, Qingdao 266061, China \\ * Correspondence: xiaojing205@hotmail.com; Tel.: +86-159-6322-0366
}

Received: 17 August 2019; Accepted: 21 August 2019; Published: 23 August 2019

\begin{abstract}
This is book review of "The Belt and Road Strategy in International Business and Administration", edited by Wei Liu, Zhe Zhang, Jinxiong Chen and Sang-Bing Tsai. This book review focuses on discussing how "The Belt and Road Strategy" develops in the current studies of international business field based on the book's content. The review begins with a literature review on current research in "The Belt and Road Strategy", then gives a brief summary of each chapter of the book, and finally concludes with its practical implication and suggestion for readership.
\end{abstract}

Keywords: The Belt and Road Strategy; international business; China

\section{Introduction}

"The Belt and Road Strategy" is a geographical initiative by the Chinese government involving infrastructure advancement and the promotion of investments that encompasses 152 countries and international organizations across Europe, Asia, the Middle East, Latin America and Africa. This seminal foreign affairs initiative intends to address economic, regional, and political demands in Eurasia, consisting of two parts, as suggested in its name, the "belt" and the "road". The "belt" refers to overland communication, which was historically referred to as "the Silk Road Economic Belt", aimed to connect underdeveloped regions in China to Europe and Central Asia, whilst "road" refers to the sea routes, or the 21st Century Maritime Silk Road, with the Indo-Pacific region as its main focus. This initiative covers more than 68 countries, including $65 \%$ of the world's population and $40 \%$ of the global gross domestic product as of 2017.

This initiative was proposed by the President of the People's Republic of China (PRC) Xi Jinping in September and October 2013 during visits to Kazakhstan and Indonesia. It was thereafter promoted by Premier Li Keqiang during state visits to Asia and Europe, and subsequently came into realization under China's National Development and Reform Commission with the involvement of the ministries of foreign affairs and commerce.

The initial focus of "The Belt and Road Strategy" is to promote infrastructure investment whilst investing in education, construction materials, railway and highway, automobile, real estate, the power grid, and iron and steel. The initiative was first proposed in October 2013 and was funded by The Asian Infrastructure Investment Bank (AIIB) which is a development bank dedicated to providing funding independent of the China Policy Bank. With the Belt and Road initiative, the AIIB aimed to address the expanding infrastructure demand across Asia whilst envisaging a future of enhanced regional integration and expanded social and economic capacity as a result of economic development and social services capacity building. 
The goal of this strategy is to address both the economic and cultural needs of the correspondent geographical area. Economically, it proposes to construct a unified continental market through rebuilding both the surplus value and human resource capacity in China whilst guaranteeing the energy and food supply externally to China. Culturally, this initiative ambitiously intends to promote the development of China's disadvantaged hinterland through the exchange of cultural resources and to enhance mutual understanding amongst member nations. This will lead to more strengthened and trustworthy partnerships with fellow states whilst constructing a comprehensive and multilevel interconnected network to achieve pluralistic, independent, balanced, and sustainable development. By promoting the exchange of cultural resources, the fundamental strategy is to build up an innovative pattern of capital inflows, a talent pool, and technology database. If adhered to, this initiative addresses the principles of co-operation and co-construction with mutual goals for more secure and efficient infrastructure, ultimately establishing a comprehensive land, sea and air communication network. At the same time, it will improve the level of investment more effectively and establish a higher-standard free trade regional network in order to strengthen economic ties, deepen mutual trust, and widen cultural exchanges among countries along the line.

Previous research has emphasised the profound significance of the Belt and Road, and many earlier studies of "The Belt and Road Strategy" are related to its impact in terms of economics, politics and security, both regionally and globally. According to Pantucci and Lain (2016), the Belt and Road Incentive has immediate economic influence by virtue of being seen from the ground in China's Eurasian neighbourhood (Pantucci and Lain 2016). Cai (2018) claims that the successful implementation of The Belt and Road Strategy could help to promote regional economic integration, boost trade and financial flows, and to expand a China-centered pattern of trade and investment in an international environment over the long term (Cai 2018). According to Liu et al. (2018), Chinese reforms contribute greatly to the construction of economic zones, such as special economic zones, hi-tech zones, and bonded zones, which boost the development of international business. The released Belt and Road Strategy after that will be icing on the cake. Ma (2015) also thinks that the Belt and Road Strategy will contribute greatly to Chinese international business, especial the cooperation between China and the Gulf Cooperation Council (GCC) through the construction of the "321Silk Road" cooperation mode (Ma 2015). Apart from the impact on international business, on the contrary, there are some studies which focus on the local impact. The research of Zhang and Chen (2018) pay more attention to local experiences the Belt and Road can build and believe that the Belt and Road provides China the opportunity to internationalise its higher education which will lead to future transformation and development (Zhang and Chen 2018).

Recent studies add more new perspectives to this topic such as international position, international law and sustainability. First of all, Andornino (2017) claims that through the Belt and Road Strategy, China's connective leadership will be strengthened (Andornino 2017). This observation is also supposed by Wang (2016) who, regarding China's contribution to international public goods, posits that this strategy conforms to the concept of "economic liberalism" and will boost China's influence and position in international institutions (Wang 2016). Secondly, He (2018) points that by enhancing international cooperation, this strategy provides the opportunity to envisage a Chinese perspective of international law and provides a useful and critical perspective to examine it (He 2018). Lastly, in 2017, two important documents were released by the Chinese government to further advance the green development of Belt and Road, namely "the Guiding Opinions on Promoting Green Belt and Road Construction" and "The Belt and Road Ecological and Environmental Cooperation Plan" (Liang and Zhang 2019). Through the analysis of Chinese enterprises and their foreign direct investments (FDIs) in countries within the Belt and Road Initiative, Hu et al. (2017) argue that it's important to deal with environmental responsibilities arising from Chinese FDIs in other Belt and Road countries (Hu et al. 2017). Additionally, Wang et al. (2018) find that free trade agreements (FTA) facilitate sustainable development, especially regarding economic sustainability (Wang et al. 2018). 
Since the obvious political intention attracts less attention from scholars, the aim of "The Belt and Road Strategy in International Business and Administration" is to cause wider and divergent concern with respect to program investment and political support, reflecting a new theoretical and practical mechanism of international business and regional administration from professionals, researchers, students, and professors working in the topic of the Belt and Road Strategy and the relative studies in international business and regional administration.

The book will strive to achieve this this goal by exploring the relationship between international business and sustainable development, providing a practical and comprehensive forum for exchanging novel research ideas or empirical practices in this topic, and also to contribute to developing theoretical, analytical, empirical research, comprehensive reviews of relevant research, conceptual frameworks, and case studies of effective applications in this area.

\section{Organization and Content of the Book}

Content and organization are two essential elements for a publication. Without exception, these will be the two main criteria when assessing this book (Liu et al. 2019).

On the one hand, content. Firstly, the authors depicted a comprehensive strategy using the both traditional theoretical framework and contrasting case studies which of great practical significance. This book has notably wide coverage. In Section 1 "International Business Studies Under the Belt and Road Strategy", it re-examines perspectives of international business such as corporate internationalization and global strategy, which are demonstrated by the Chinese development model under such aspectes: (1) the new global political environment (Kar and Eğri 2019); (2) corporate social responsibility of Chinese firms and its development, risk and strategic decision-making (Chen and Liu 2019); (3) Chinese firms improvement of their competitiveness in order to adapt to the international market (Zhou and Wong 2019); (4) the importance of intellectual property protection. aiming to provide the strategies for intellectual property under the belt and road strategy (Zhou et al. 2019a, 2019b; Zhang 2019). In Section 2 "Industrial and Trade Development Studies Under the Belt and Road Strategy", the authors use a multimodal transport cost model to analyze cost and time components of shipping trade; the competitiveness of coal railway transportation; motivation and development of the Chinese electrolytic aluminum industry, and the aim to promote collaborative innovation combined with the regionalization strategy (Baştuğ and Battal 2019; Li et al. 2019; Zhou et al. 2019c). In Section 3 "Regional Case Studies Under the Belt and Road Strategy", there are three main case studies from different countries: Macau as an important geographic node; the synergistic development effect of the belt and road strategy to promote cooperation and the development of the economy, trade, politics and human resources in Malaysia; Mongolian tourism, pointing out the new opportunities for tourism afforded by the belt and road strategy (Zhou et al. 2019d; Chuin 2019; Han and Li 2019). Secondly, the content provides multi-level perspectives which will inspire scholars in their corresponding areas in a motivational and guiding way. The book features research on a great number of topics involving business development, business law, corporate strategy, foreign investment, infrastructure investment, multinational enterprise, regional administration, social responsibility, trade cooperation, transport, and logistics, which benefits scholars from each subject area above. Lastly, the content is objective although the main authors are from China which is the ultimate beneficiary of "The Belt and Road Strategy". This ensures the fairness principle of academic research.

The shortcomings lay in the following facts. The book lacks real cases from the internationalization of Chinese corporations under "The Belt and Road Strategy" but uses many comparable case studies to verify the argument from the other side. Moreover, there are no sufficient comparisons of the differences between relevant policies and regulations in China and other countries involved in "The Belt and Road Strategy", which is of significance when analyzing multinational corporations. Besides, as mentioned in the book, all the development processes are not stable, which means there will be changes in both the short- and long-term. This may lead to the conclusion that the universalism of the book is weakened. But these weak points also illuminate the subsequent researches. 
On the other hand, we note the organization, that is, the book's structure. There are three sections, each with between three and six chapters. Each chapter elaborates a strategy or model with decomposition and analysis in detail. Therefore, every part seems distinct with wide coverage, but at the same time, they are integrated organically into a harmonious whole. This definitely helps to show a clear and logical structure. When showing the comprehensive concepts and cases, it follows layers of progression, from the elementary to the profound. Therefore, from the first glance at the table of contents, readers will immediately get to know what is inside and how the authors will illustrate it. However, case studies are not incorporated into the conceptual framework but rather juxtaposed with it, which makes the structure a little asymmetric. Further, because the content serves the models too much, this disrupts the structure a little.

All in all, the content of the book is full and comprehensive, as well as the structure is clear and organized. It helps readers to easily and overall comprehend "The Belt and Road Strategy".

\section{Conclusions and Readership}

This publication is highly recommended for the following reasons. First and most importantly, the content is strongly correlated with the current development and progress in Chinese politics and economy. The book can be seen as a product of China's rapidly evolving society, and it fills up the vacancy of academic publication in this project area. Moreover, the expressions and writing techniques in the book are succinct and concise, which helps general readers to understand such a comprehensive concept without a great deal of effort. The logic, which is demonstrated by the book's organized structure, is clear, and this also helps to sketch the blueprint in the reader's mind. Last but not least, this book provides target audients with a great foundation for their research on "The Belt and Road Strategy" and more perspectives to inspire subsequent, relevant research.

It can be easily identified that the following groups of people will benefit tremendously from the book. Firstly, students who study in international business and public policy, or are simply interested in these topics, like me, will find an overview about "The Belt and Road Strategy" in this all-in-one reference book. Meanwhile, the book offers researchers in this project area immense support for their academic performance with its multilevel content from the elementary to the profound, which means scholars from any stage of their research will get help from it. Secondly, multinational enterprises will have the real current situation in hand after reviewing this book, since the book will provide a deep insight of the nature of "The Belt and Road Strategy", and enterprises will find their own ways to profit and enhance the market under this strategy. Lastly, policymakers and government officials from other countries may benefit from going through this book. By drawing on the experiences of China and combining this with the real situations in their own countries, policymakers will be able to deliver better and appropriate governance and management.

Funding: This work was supported by the National Social Science Fund Youth Project of China (Grant No. 17CJY019).

Conflicts of Interest: The authors declare no conflict of interest.

\section{References}

Andornino, Giovanni B. 2017. The Belt and Road Initiative in China's Emerging Grand Strategy of Connective Leadership. China \& World Economy 25: 4-22.

Baştuğ, Sedat, and Turgay Battal. 2019. An Assessment of the Belt and Road Performance: Based on the Case of Machinery Shipment from Shanghai to Rotterdam. In The Belt and Road Strategy in International Business and Administration. Hershey: IGI Global, pp. 108-27.

Cai, Kevin G. 2018. The One Belt One Road and the Asian Infrastructure Investment Bank: Beijing's New Strategy of Geoeconomics and Geopolitics. Journal of Contemporary China 27: 831-47. [CrossRef] 
Chen, Jianyu, and Wei Liu. 2019. The Belt and Road Strategy in International Business and Administration: Corporate Social Responsibility. In The Belt and Road Strategy in International Business and Administration. Hershey: IGI Global, pp. 28-51.

Chuin, Teo Poh. 2019. Belt and Road Initiative: The Case of Malaysia. In The Belt and Road Strategy in International Business and Administration. Hershey: IGI Global, pp. 176-99.

Han, Huilian, and Hui Li. 2019. Opportunities of Tourism Development of Mongolia Under the Belt and Road Initiative. In The Belt and Road Strategy in International Business and Administration. Hershey: IGI Global, pp. 200-14.

He, Chi. 2018. The Belt and Road Initiative as Global Public Good: Implications for International Law. In Normative Readings of the Belt and Road Initiative. Edited by Wenhua Shan, Kimmo Nuotio and Kangle Zhang. Cham: Springer, pp. 85-104.

$\mathrm{Hu}$, Desheng, Jun Ou, and Xueyue Hu. 2017. On the Environmental Responsibility of Chinese Enterprises for Their FDIs in Countries within the Belt and Road Initiative. In Normative Readings of the Belt and Road Initiative. Edited by Wenhua Shan, Kimmo Nuotio and Kangle Zhang. Cham: Springer, pp. 183-206.

Kar, Bahar Baysal, and Taha Eğri. 2019. The China Model in the Global Economy. In The Belt and Road Strategy in International Business and Administration. Hershey: IGI Global, pp. 1-27.

Li, Shiqi, Maoxiang Lang, Xueqiao Yu, Yanling Wang, and Xiao Yu. 2019. The Analysis on Railway Transportation Competitiveness and Influencing Factors of Typical Goods in Beijing-Tianjin-Hebei Region: A Case of Coal Transportation. In The Belt and Road Strategy in International Business and Administration. Hershey: IGI Global, pp. 128-49.

Liang, Haoguang, and Yaojun Zhang. 2019. Green Development: Belt and Road is Global and Rational. In The Theoretical System of Belt and Road Initiative. Edited by Haoguang Liang and Yaojun Zhang. Singapore: Springer, pp. 35-38.

Liu, Wei, Hong-Bo Shi, Zhe Zhang, Sang-Bing Tsai, Yuming Zhai, Quan Chen, and Jiangtao Wang. 2018. The Development Evaluation of Economic Zones in China. International Journal of Environmental Research and Public Health 15: 56. [CrossRef] [PubMed]

Liu, Wei, Zhe Zhang, Jin-Xiong Chen, and Sang-Bing Tsai. 2019. The Belt and Road Strategy in International Business and Administration. Hershey: IGI Global.

Ma, Lirong. 2015. The 'One Belt, One Road' Strategy and the '321' Cooperation Mode between China and GCC. Journal of Sino-Western Communications 7: 119-20.

Pantucci, Raffaello, and Sarah Lain. 2016. I. China's Grand Strategy: The Belt and Road Initiative. Whitehall Papers 88: 7-16. [CrossRef]

Wang, Yong. 2016. Offensive for defensive: The belt and road initiative and China's new grand strategy. The Pacific Review 29: 455-63. [CrossRef]

Wang, Hexian, Wei Liu, Mengyuan Zhu, and Qing Wang. 2018. Embrace or Not? An Empirical Study of the Impact of Globalization on the Country's Sustainability in the Case of NAFTA. Sustainability 10: 3436. [CrossRef]

Zhang, Yong. 2019. Intellectual Property Protection Strategy Under the Belt and Road Initiative. In The Belt and Road Strategy in International Business and Administration. Hershey: IGI Global, pp. 82-106.

Zhang, Zhou Zhou, and Yue Chen. 2018. A study on the Path of Internationalization Transformation and Development of Higher Education Under the Strategy of "Belt and Road". Educational Sciences: Theory $\mathcal{E}$ Practice 18: 2363-72.

Zhou, Ping, and Tim Wong. 2019. The "Outgoing Strategy" of Chinese Companies. In The Belt and Road Strategy in International Business and Administration. Hershey: IGI Global, pp. 52-57.

Zhou, Ping, Dongjuan Lv, and Ying Chen. 2019a. The Study of Intellectual Property Protection System: Under the Context of "One Belt One Road". In The Belt and Road Strategy in International Business and Administration. Hershey: IGI Global, pp. 58-66.

Zhou, Ping, Fuda Li, and Linling Zhong. 2019b. Research on Protection and Development of Intellectual Property in China from the Perspective of "The Belt and Road". In The Belt and Road Strategy in International Business and Administration. Hershey: IGI Global, pp. 67-81. 
Zhou, Ping, Gexin Han, and Xinyao Li. 2019c. The Development of Electrolytic Aluminum Industry and the Belt and Road Strategy: A Collaborative Innovation Perspective. In The Belt and Road Strategy in International Business and Administration. Hershey: IGI Global, pp. 150-62.

Zhou, Ping, Zhanwen Zhang, and Siwei Sun. 2019d. Making Use of Geographic Advantage: Building “One Belt One Road" Vital City. In The Belt and Road Strategy in International Business and Administration. Hershey: IGI Global, pp. 164-75. 